\title{
Cytological Study of Gender Conversion in Amur Grape
}

\author{
Hailin Shen \\ College of Horticulture, Shenyang Agricultural University, 120 Dongling Road, 110866 Shenyang, \\ Liaoning, China; and Institute of Pomology, Jilin Academy of Agricultural Science, 136100 \\ Gongzhuling, Jilin, China \\ Zhendong Liu' \\ College of Horticulture, Shenyang Agricultural University, 120 Dongling Road, 110866 Shenyang, \\ Liaoning, China \\ Ke Yan, Liren Zou, and Jinghui Wen \\ Institute of Pomology, Jilin Academy of Agricultural Science, 136100 Gongzhuling, Jilin, China \\ Yinshan Guo, Kun Li, and Xiuwu Guo ${ }^{1}$ \\ College of Horticulture, Shenyang Agricultural University, 120 Dongling Road, 110866 Shenyang, \\ Liaoning, China
}

\begin{abstract}
AdDitional INDEX wORDS. embryo sac, nucellus, programmed cell death, Vitis amurensis
Abstract. Amur grape (Vitis amurensis) is a dioecious species. To elucidate the time of and reason for pistil abortion in male amur grape from the perspective of cytology, we observed the sections of pistil of a male line during its development using optical and transmission electron microscopes. The abnormity in the morphology of nucellar cell and the development of various organelles appeared before the abnormity of functional megaspore mitosis. Programmed cell death (PCD) of the nucellar cells might be an important reason for mitosis disorder, leading to the abortion of pistil in male flower. However, the abortion can be eliminated by forchlorfenuron treatment, resulting in the recovery of functional pistil in male amur grape. This study provides cytological information on the gender conversion mechanism in male amur grape, which can promote gender determination studies in Vitis species.
\end{abstract}

The wild amur grape is a dioecious species, mostly cultivated for wine production in China (Song et al., 2000). It is the hardiest species within the genus Vitis and can tolerate temperatures as low as $-40{ }^{\circ} \mathrm{C}$ (Jiao et al., 2015; Ma et al., 2010). Therefore, it is a widely used species for grapevine coldhardiness research (Dubrovina et al., 2015; Li et al., 2013) and for hardy cultivar breeding (Zhang et al., 2015). Furthermore, amur grape is resistant to various diseases incited by fungi, such as Uncinula necator, Plasmopara viticola, and Coniothyrium diplodiella (Li et al., 2008; Wan et al., 2007). Currently, several genes or quantitative trait loci that improve downy mildew resistance have been identified in amur grape (Blasi et al., 2011; He et al., 2017; Li et al., 2015a). Since the 1950s, China has been working on the collection, evaluation, and utilization of amur grape (Li et al., 2015b). In 1963, the first hermaphrodite plant, which was released later as a cultivar named Shuangqing in 1982, was discovered in this naturally dioecious species (Huang, 1980). Since then, the direction of research with amur

Received for publication 4 Apr. 2018. Accepted for publication 27 June 2018. The present study was financially supported by the National Natural Science Funds of China (grant number 31501722), China Agriculture Research System (grant numbers CRAS-30-yz-6 and nytycx-29), Liaoning Province Doctor Startup Fund (grant number 20141060), and Agricultural Science and Technology Innovation Program of Jilin Province (grant number C72080705). We sincerely thank Jun Ai and his research team for providing the plant material used in the present study.

${ }^{1}$ Corresponding authors. E-mail: leoliuzd@163.com or guoxw1959@163. com. grape has turned from wild resource selection to sexual crossbreeding (Li et al., 2015b).

The gender of plants has long been a hotspot for plant researchers. They have mainly focused on model plants, such as Silene latifolia (Charlesworth, 2002; Lardon et al., 1999; Matsunaga et al., 1996; Scutt et al., 1997), Zea mays (Bensen et al., 1995; DeLong et al., 1993), and Cucumis sativus (Kamachi et al., 1997, 2000; Knopf and Trebitsh, 2006; Mibus and Tatlioglu, 2004; Trebitsh et al., 1997; Yamasaki et al., 2000,2001 ). The dioecious amur grape is an ideal species for studies on the gender of perennial woody plants. In grapevine, it has been reported that not only cytokinin treatment (Hashizume and Iizuka, 1971; Iizuka and Hashizume, 1968; Moore, 1970; Negi and Olmo, 1966), but also ethephon treatment (Kender and Remaily, 1970) can convert male flowers to hermaphrodite flowers. Studies in northeast China have mainly focused on the effects of cytokinin on amur grape. For instance, Ai et al. (2002) compared different effects of 6-benzylaminopurine (6-BA) and $\mathrm{N}_{1}$-(2-chloro-4-pyridyl)- $\mathrm{N}_{3}$-phenylurea (CPPU) on gender conversion efficiency in male amur grape and found that CPPU was more efficient, resulting in a fruit setting rate of $96.7 \%$. Xu et al. (2013) analyzed proteomic changes during the gender conversion of male amur grape and found a key protein that was upregulated by CPPU, which resulted in the ability to fruit at the end.

The gender conversion studies in amur grape have opened a new direction for germplasm innovation, providing some evidence on gender differentiation mechanism in Vitis species. In the present study, we 1) focused on the abortion of pistil and 
its recovery from the perspective of cytology and 2) aimed to provide a more theoretical basis for gender determination mechanism in amur grape.

\section{Materials and Methods}

Plant materials and CPPU treatment. Male amur grape (accession no. 043) was used as the study material. The plants were grown in the National Field Gene Bank for Amur Grapevine, Zuojia, Jilin. The inflorescences were dipped in CPPU solution $\left(75 \mathrm{mg} \cdot \mathrm{L}^{-1}\right.$ ) for $5 \mathrm{~s}$ on 19 May 2016. The control inflorescences were treated with water. The flower buds were then collected on days 3, 6, 9, and 12 after treatment. The inflorescences developed to flowers on day 12 after treatment, 31 May 2016.

ObSERVATION OF PISTIL DEVELOPMENT. Ten flower buds were collected at each sampling time. After stripping the caps, the morphology of pistil was observed using a stereomicroscope (SZX7; Olympus, Tokyo, Japan), and the vertical and transverse diameters were measured by its self-contained measuring software. The statistical difference between the treated and control pistils collected on day 12 after treatment was analyzed by the $t$ test using the analysis pack in Excel (Microsoft, Redmond, WA).

STATIONARY LIQUID PREPARATION AND SECTIONING. The flower bud samples were preserved in formaldehyde-alcohol-acetic acid stationary liquid [5 $\mathrm{mL}$ of formalin (38\% formaldehyde), $5 \mathrm{~mL}$ of glacial acetic acid, and $90 \mathrm{~mL}$ of $50 \%$ ethyl alcohol] to prepare paraffin sections and in glutaraldehyde-paraformaldehyde stationary liquid $\left[50 \mathrm{~mL}\right.$ of $0.2 \mathrm{~mol} \cdot \mathrm{L}^{-1}$ phosphate buffer $(\mathrm{pH}=7.4), 20 \mathrm{~mL}$ of $10 \%$ paraformaldehyde, $10 \mathrm{~mL}$ of $25 \%$ glutaraldehyde, and $20 \mathrm{~mL}$ of redistilled water] to prepare sections for transmission electron microscopy (TEM). The paraffin sections of $10-\mu \mathrm{m}$ thickness were prepared following dehydration, transparency, waxdip, and embedment. The sections were then stained with safranin-fast green dye and sealed with neutral balsam. After desiccation, the sections were observed using an optical microscope (BA310; Motic, Xiamen, China). To prepare the sections for TEM, young flower buds were quickly dipped in glutaraldehyde-paraformaldehyde stationary liquid and incubated for more than $24 \mathrm{~h}$. After incubation, the materials were washed with phosphate buffer and dehydrated with gradient concentrations of ethyl alcohol ( $70 \%$, $85 \%, 95 \%$, and $100 \%$ ), and then sealed with resin. The sections of thickness $90 \mathrm{~nm}$ were obtained using an ultramicrotome (EM UC7; Leica, Wetzlar, Germany), double stained with uranyl acetate-lead citrate, and observed using a transmission electron microscope (HT7700; Hitachi, Tokyo, Japan).

\section{Results}

EFFect of CPPU TREATMENT ON THE DEVELOPMENT OF PISTIL. With the development of flower, the CPPU-treated pistil gradually expanded, forming an obviously inflated pistil on day 12 after treatment. However, there were no obvious changes in the size of control pistil during the development of flower (Fig. 1). The vertical and transverse diameters of the treated pistil were 2.322 and $1.319 \mathrm{~mm}$, respectively, on day 12 after treatment, whereas, those of the control were only 0.895 and $0.759 \mathrm{~mm}$, respectively (Fig. 2). Compared with those of the control, the vertical and transverse diameters of the CPPUtreated pistil increased significantly by $159 \%$ and $73.8 \%$, respectively.
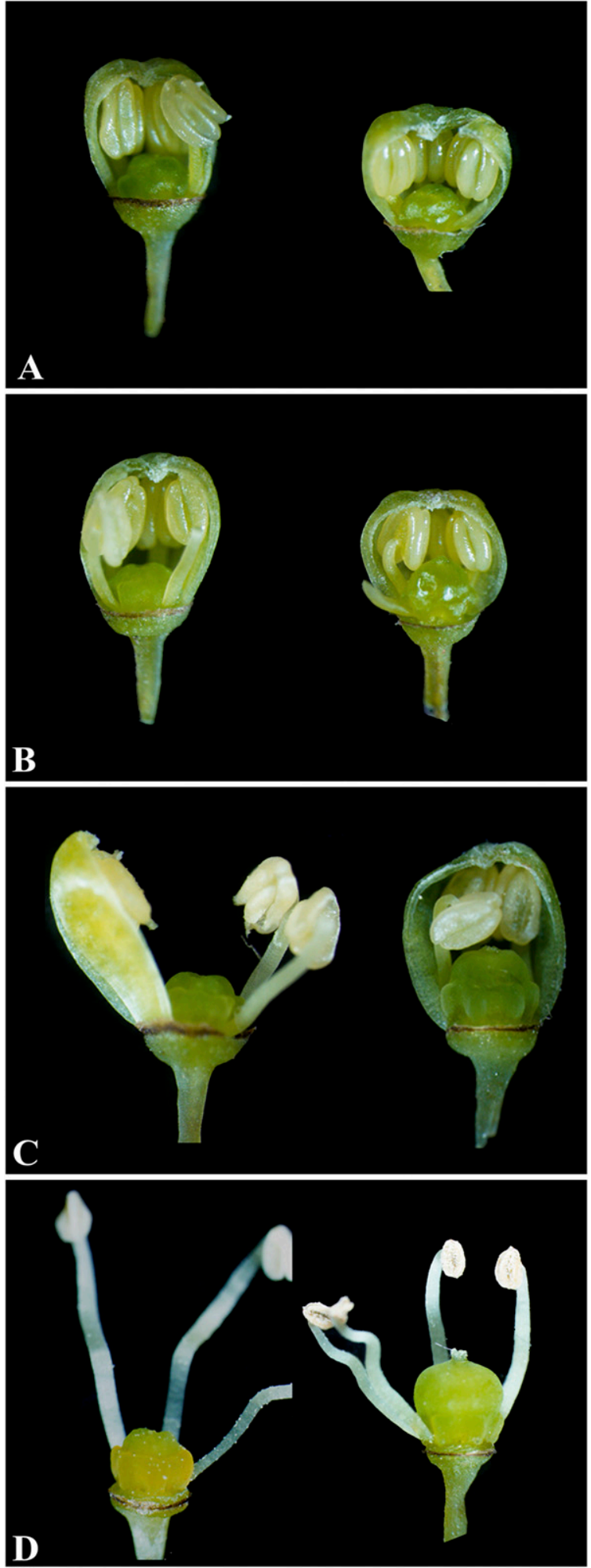

Fig. 1. Dissected buds of male amur grape, observed using a stereomicroscope, showing changes in the size of pistils in $\mathrm{N}_{1}$-(2-chloro-4-pyridyl)- $\mathrm{N}_{3}$ phenylurea-treated (right) and control (left) flowers: (A) day 3 after treatment, (B) day 6 after treatment, (C) day 9 after treatment, and (D) day 12 after treatment $($ magnification $=\times 2.5)$.

EFFECT OF CPPU TREATMENT ON FRUIT PRODUCTION AND SEED FORMATION. Under natural condition, male amur grape cannot bear fruit, and its inflorescences wither and fall (Fig. 3A). 


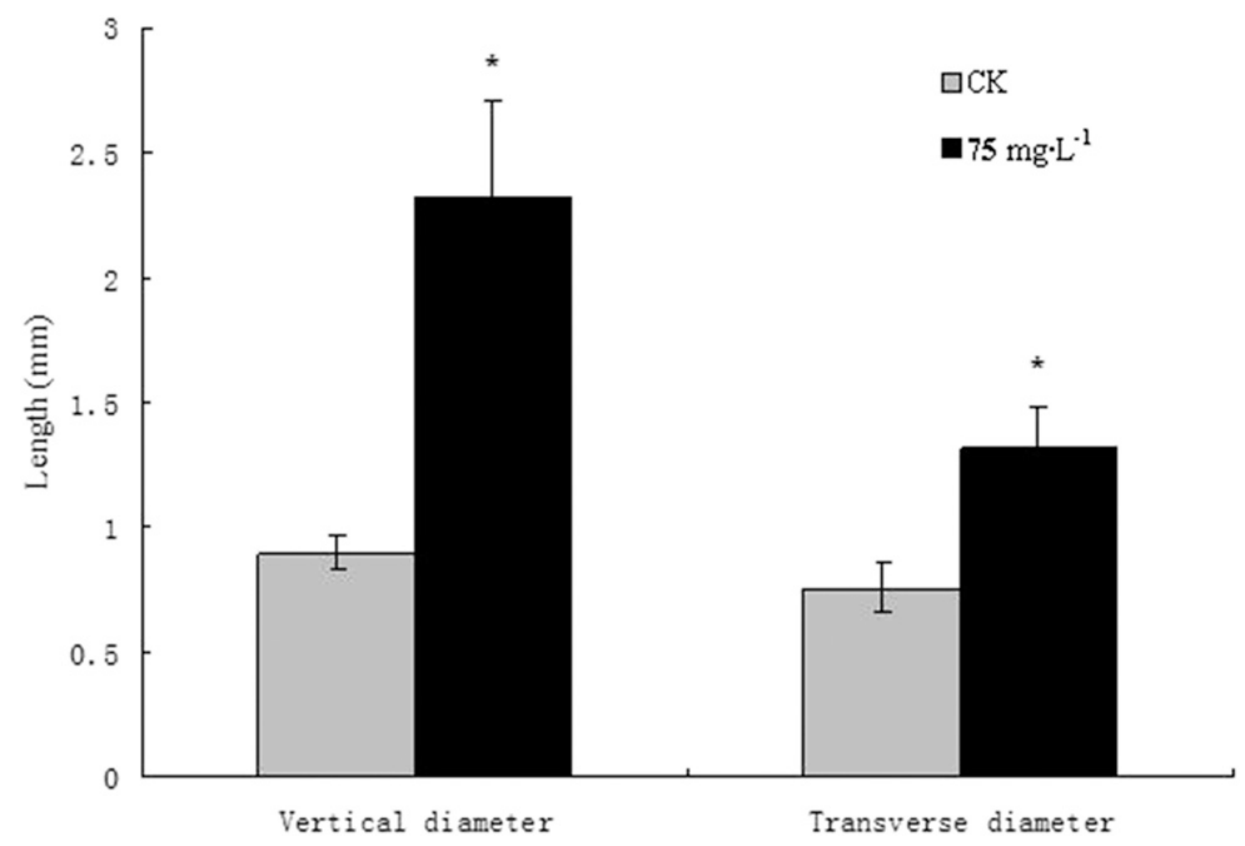

Fig. 2. Effects of $\mathrm{N}_{1}$-(2-chloro-4-pyridyl)- $\mathrm{N}_{3}$-phenylurea treatment vs. a control (CK) on the vertical and transverse diameters of pistils of male amur grape on day 12 after treatment. *Significant difference at $P \leq 0.05$.

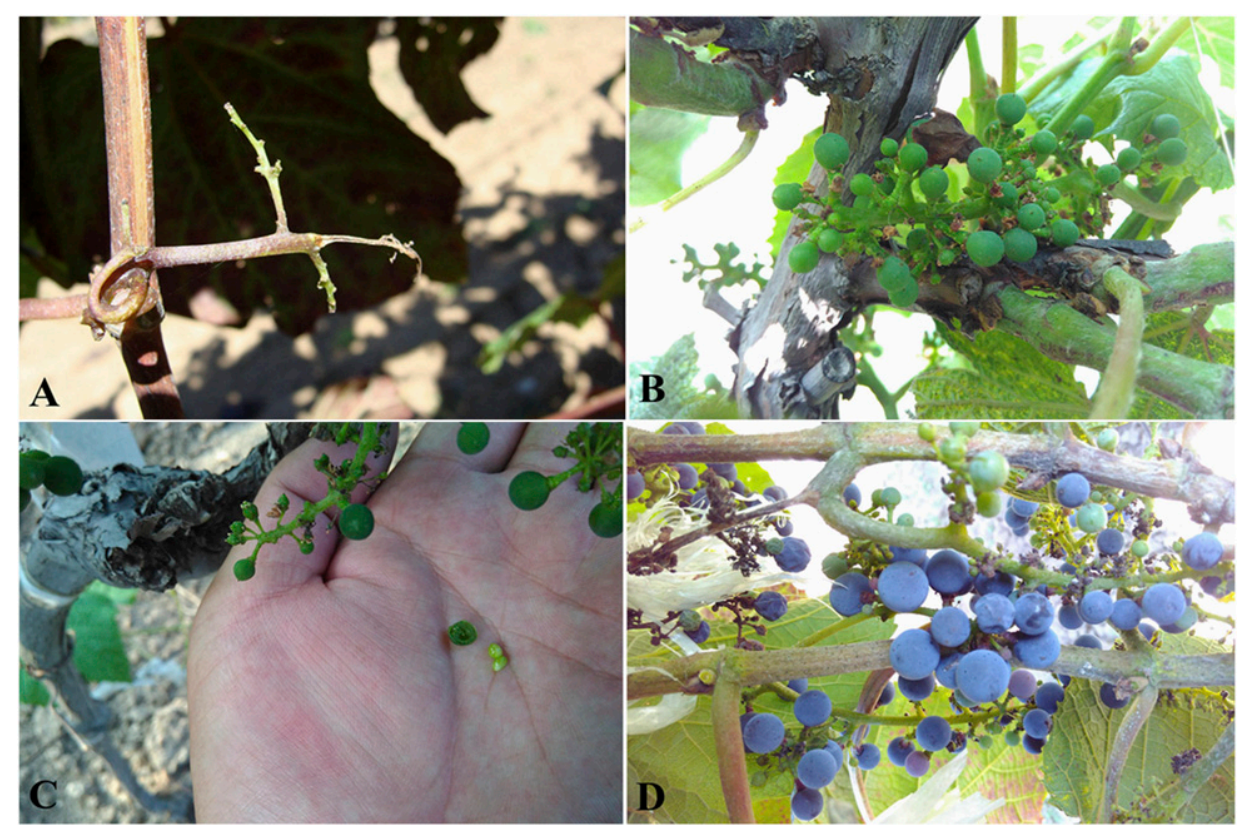

Fig. 3. Withered inflorescence of control male amur grape (cluster, seeds, and fruit) produced by $\mathrm{N}_{1}$-(2-chloro-4pyridyl)- $\mathrm{N}_{3}$-phenylurea-treated male amur grape: (A) withered inflorescence, (B) young fruit cluster, (C) green seeds, and (D) ripe fruit.

However, the treated inflorescence continued its development and formed a young fruit cluster (Fig. 3B). Furthermore, green seeds were revealed when the flesh of a pea-sized young fruit was stripped (Fig. 3C); eventually, ripe fruit were produced (Fig. 3D). These findings indicate that the reproductive function of pistil, which was supposed to have been aborted, can be recovered with CPPU treatment.

OBSERVATION OF THE OVULE MORPHOLOGY AND FUNCTIONAL MEGASPORE MITOSIs. The morphological differences in the ovule of treated and control flowers were observed at each development stage. On day 3 after treatment, an anatropous ovule consisting of a near round-shaped nucellus tissue and double layer of integument was formed in the treated flowers. The inner integument was almost connected at the micropylar end, whereas the outer integument was not connected (Fig. 4B). However, in the control flower, an irregularshaped ovule was formed (Fig. 4A). At this development stage, a singlenucleate embryo sac was formed in both treated and control flowers (Fig. 4A and B). On day 6 after treatment, a regular oval-shaped ovule was formed in the treated flower, and the outer cell layers of both the integument and nucellus tissue were darkly stained and orderly arranged, showing two distinguishable ovule structures, the integument and nucellus (Fig. 4H). However, in the control flower, only the outer layer of the integument was darkly stained, and the boundary of the integument and nucellus tissue was difficult to identify, leaving a gap outside the nucellus (Fig. 4C). At this stage of development, a double-nucleate embryo sac was formed in both treated and control flowers (Fig. 4C and D). On day 9 after treatment, the irregularity of nucellus shape intensified in the control flower. Furthermore, difference in mitosis appeared at this time. A normal four-nucleate embryo sac developed in the treated flower, whereas an abnormal threenucleate embryo was observed in the control flower (Fig. 4E and F). On day 12 after treatment, a typical mature embryo sac containing eight nuclei was formed in the treated flower (Fig. 5A-C). However, mitosis stagnated in the control flower, still showing an abnormal threenucleate embryo sac (Fig. 4G).

NuCELlar CELL MORPHOLOGY AND ULTRAMICROSTRUCTURE OF ORGANELLES. No obvious difference was observed in the nucellar cell between treated and control flowers on day 3 after treatment. The nucellar cells in both treated and control flowers exhibited a polyhedron shape and were orderly arranged (Fig. 6A and B). However, on day 6 after treatment, the cell morphology showed significant differences between the treated and control flowers. In the treated flower, the nucellar cell exhibited a regular shape with orderly arrangement (Fig. 6D); however, the shape of nucellar cell was highly irregular in the control flower (Fig. 6C). The morphological abnormity of nucellar cell in the control flower 


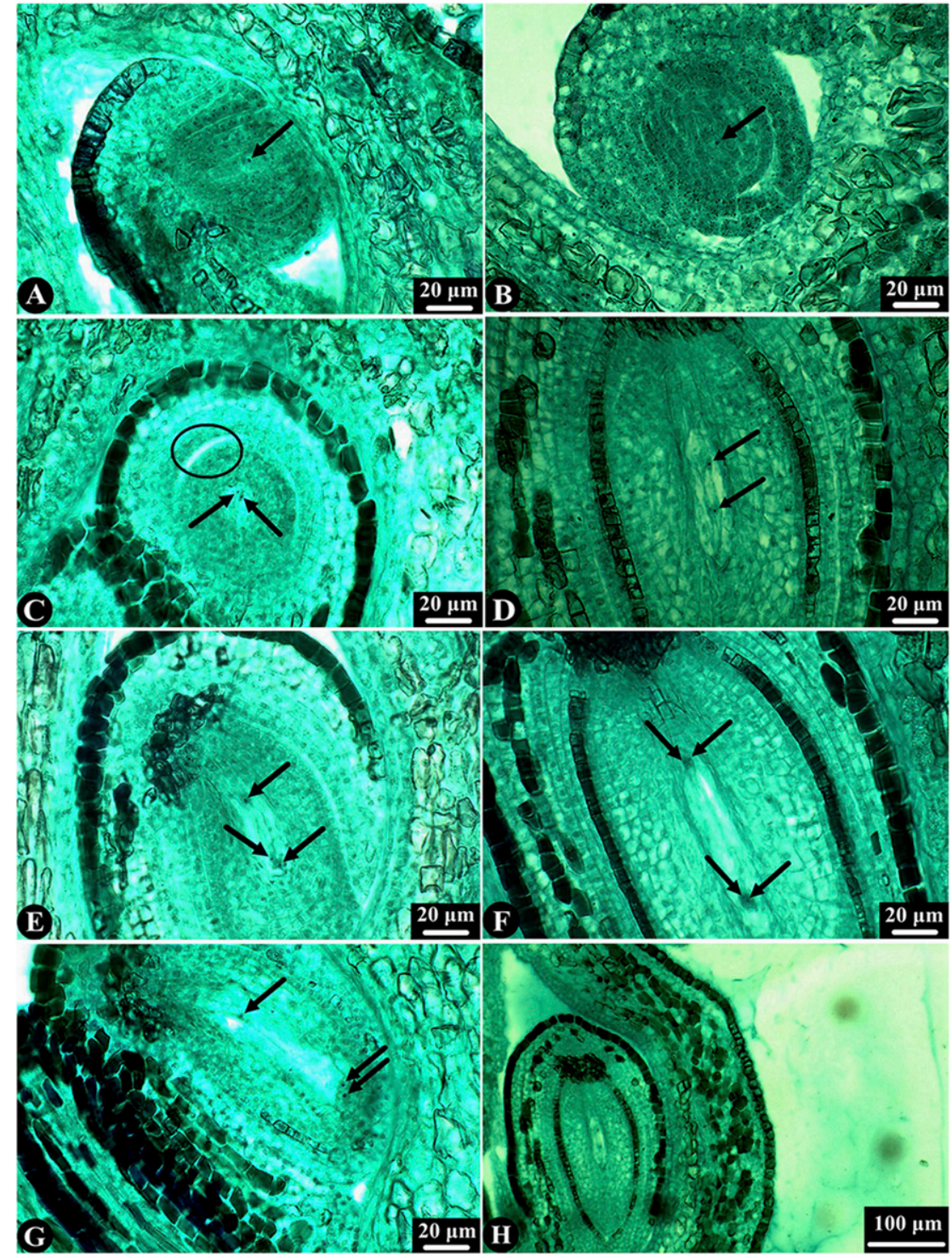

Fig. 4. Optical micrographs of $\mathrm{N}_{1}$-(2-chloro-4-pyridyl)- $\mathrm{N}_{3}$-phenylurea-treated (right) and control (left) male amur grape embryo sacs, showing the process of functional megaspore mitosis: (A and $\mathbf{B}$ ) day 3 after treatment, showing a single-nucleate embryo sac (arrowhead); (C) day 6 after treatment, showing a double-nucleate embryo sac (arrowhead) and a gap between the nucellus and integument (circle); (D) day 6 after treatment, showing a double-nucleate embryo sac (arrowhead); (E) day 9 after treatment, showing an abnormal threenucleate embryo sac (arrowhead); (F) day 9 after treatment, showing a normal four-nucleate embryo sac (arrowhead); (G) day 12 after treatment, showing an abnormal three-nucleate embryo sac (arrowhead); and (H) day 12 after treatment, showing a complete ovule structure (scale bars: $\mathbf{A}-\mathbf{G}=20 \mu \mathrm{m} ; \mathbf{H}=100 \mu \mathrm{m}$ ).

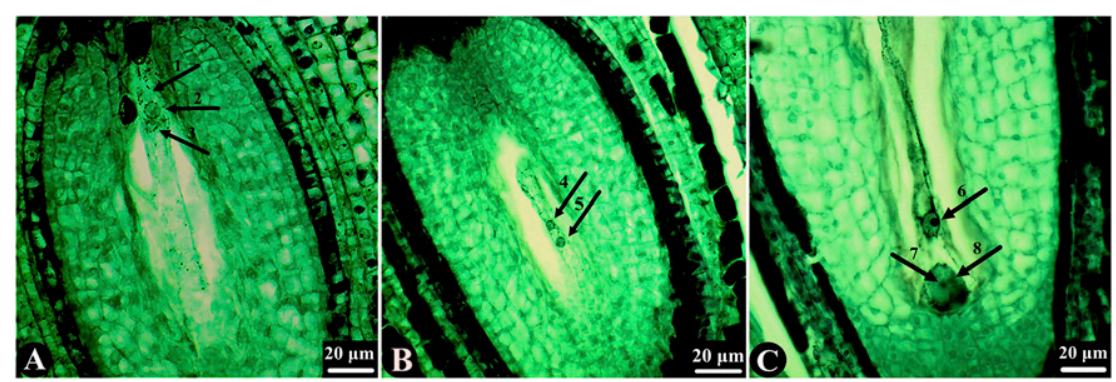

Fig. 5. Optical micrographs of $\mathrm{N}_{1}$-(2-chloro-4-pyridyl)- $\mathrm{N}_{3}$-phenylurea-treated male amur grape embryo sac on day 12 after treatment, showing a mature eight-nucleate embryo sac: (A) embryo sac with three antipodal cells (arrowhead); (B) embryo sac with two polar nuclei (arrowhead); and (C) embryo sac with an egg cell and two synergids (arrowhead) (scale bars $=20 \mu \mathrm{m})$. might be an indication of the subsequent disorder of functional megaspore mitosis.

On day 6 after treatment, the organelle development in nucellar cell showed significant differences between the treated and control flowers. The cytoplasm of nucellar cell in the control flower was concentrated to a certain region and the organelles were also difficult to recognize (Fig. 7A). This might be attributed to the degradation of various organelles. However, in the nucellar cell of the treated flower, the organelles, including cell nucleus (Fig. 7B), chloroplasts (Fig. 7C), mitochondria (Fig. 7D), Golgi apparatus (Fig. 7E), and endoplasmic reticulum (Fig. 7F), were visible.

\section{Discussion}

GENDER DIFFERENTIATION MODEL OF AMUR GRAPE. The gender differentiation model of dioecious species can be divided into two types, models I and II (Mitchell and Diggle, 2005). In model I, both stamen and pistil primordia are formed during the bisexual stage. Subsequently, with the function of the gender determining gene either stamen or pistil primordium stops its development at a certain stage, whereas the other primordium continues its development to form a unisexual male or female flower (Aryal and Ming, 2014; Ming et al., 2011; Mitchell and Diggle, 2005). Zea mays (Cheng et al., 1983), C. sativus (Kater et al., 2001), S. latifolia (Farbos et al., 1997), Rhapis subtilis (Dransfield et al., 2008), Asparagus officinalis (Park et al., 2003), Swietenia macrophylla (Gouvêa et al., 2008), Rumex acetosa (Ainsworth et al., 2005), and Vitis vinifera ssp. silvestris (Caporali et al., 2003) belong to model I. However, in model II, flower development bypasses the bisexual stage, and both the stamen and pistil primordium do not occur. Spinacia oleracea (Sherry et al., 1993), Thalictrum dioicum (Di Stilio et al., 2005), Populus deltoides (Kaul, 1995), and Hedyosmum orientale (Cui et al., 2011) belong to model II. In the present study, functional pistils were recovered in male flowers by 


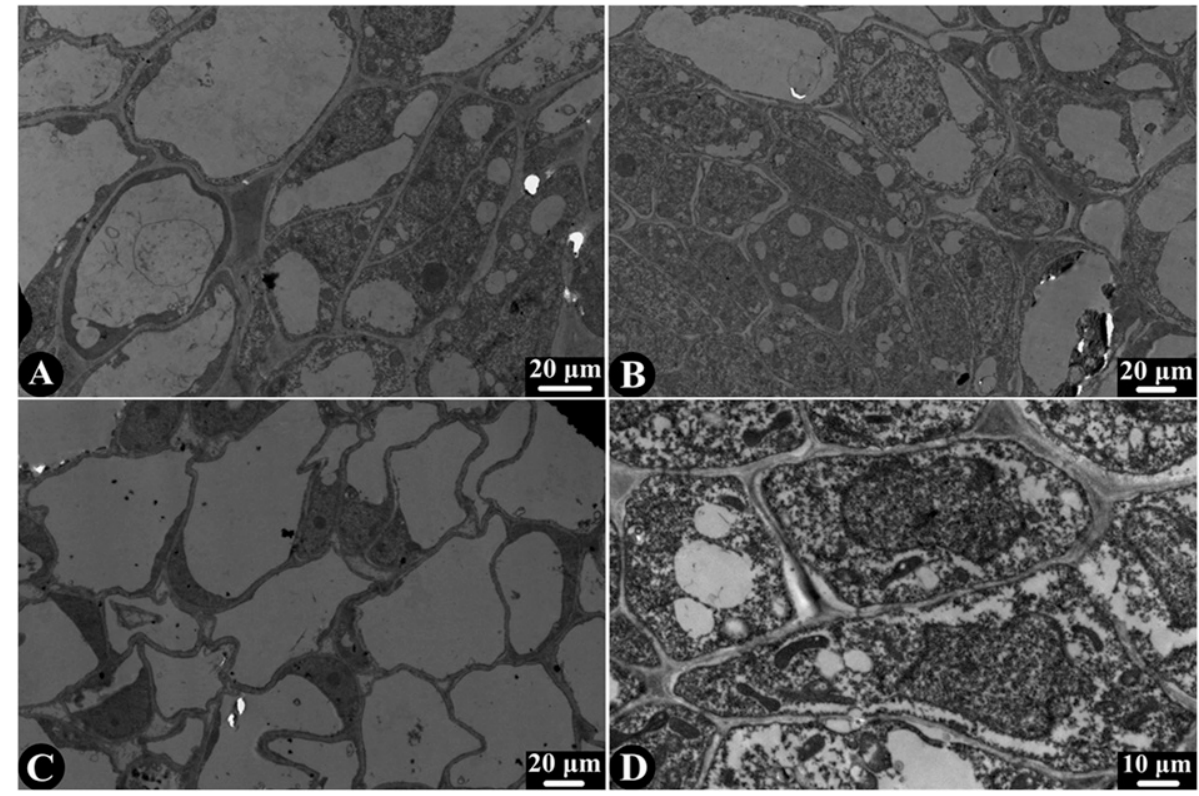

Fig. 6. Morphology of nucellar cells of $\mathrm{N}_{1}$-(2-chloro-4-pyridyl)- $\mathrm{N}_{3}$-phenylurea-treated (right) and control (left) male amur grape: (A and B) day 3 after treatment, showing polyhedron-shaped and orderly arranged nucellar cells; (C) day 6 after treatment, showing irregular-shaped nucellar cells; and (D) day 6 after treatment, showing regular-shaped nucellar cells (scale bars: $\mathbf{A}-\mathbf{C}=20 \mu \mathrm{m} ; \mathbf{D}=10 \mu \mathrm{m}$ ).

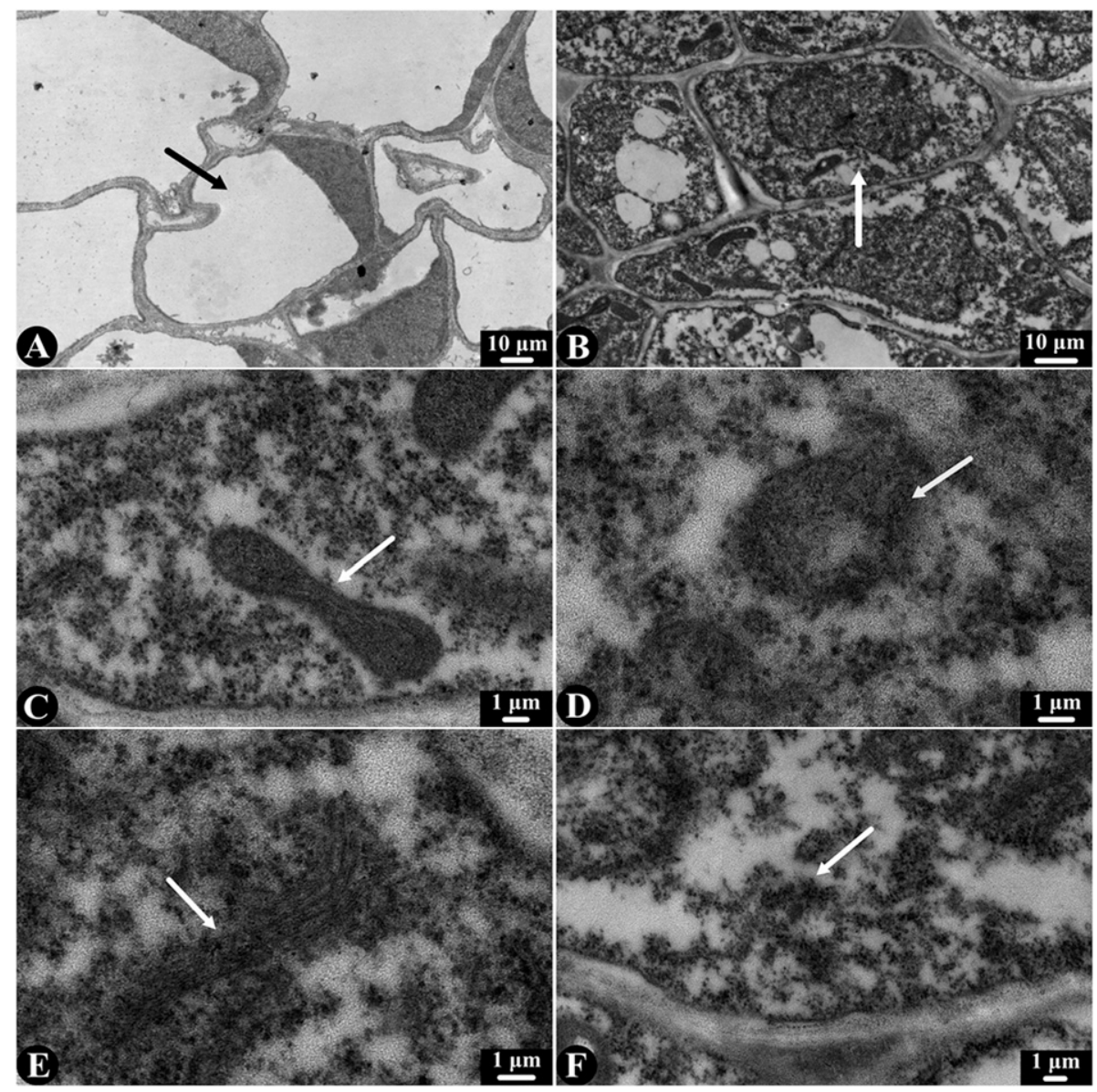

Fig. 7. A whole nucellar cell of $\mathrm{N}_{1}$-(2-chloro-4-pyridyl)- $\mathrm{N}_{3}$-phenylurea (CPPU)-treated (B) and control (A) male amur grape and the ultrastructure of nucellar organelles of CPPU-treated $(\mathbf{C}-\mathbf{F})$ male amur grape on day 6 after treatment: (A and B) a whole nucellar cell, (C) chloroplast (arrowhead), (D) mitochondrion (arrowhead), (E) Golgi apparatus (arrowhead), and (F) endoplasmic reticulum (arrowhead) (scale bars: $\mathbf{A}, \mathbf{B}=10 \mu \mathrm{m} ; \mathbf{C}-\mathbf{F}=1 \mu \mathrm{m}$ ).
CPPU treatment, indicating the formation of pistil primordia. Therefore, according to Mitchell and Diggle (2005), gender differentiation in amur grape belongs to model I.

TIME OF PISTIL ABORTION IN MALE AMUR GRAPE. The stagnation of development of female organ occurs at different stages in different plant species. In male flowers of mahogany, the ovule primordia degenerate quickly as soon as they are formed (Gouvêa et al., 2008). However, in Consolea spinosissima, the ovules of the staminate flowers degenerate after complete maturation of the embryo sac (Strittmatter et al., 2002). In Gymnocladus dioicus, the pistil aborts when the megasporocyte is formed in the nucellus (Hou et al., 2005). In the present study, the stagnation of pistil development in male amur grape occurred before the formation of four-nucleate embryo sac, and this is consistent with the findings of a previous study in amur grape (Wang et al., 2013). According to the time of division reported by Diggle et al. (2011), the abortion of the female organ in amur grape happens at stage three (postmeiosis). However, in European grape, pistil growth is retarded at prophase of the first meiotic division (Caporali et al., 2003). Therefore, the abortion of the female organ happens at different stages in amur grape and $V$. vinifera. This suggests that these two species may have evolved the mechanism of gender differentiation independently, at least for male plants.

REASON FOR PISTIL ABORTION IN MALE AMUR GRAPE. The reasons of female organ abortion include cell death, PCD, parenchymatization, arrest of development or no development, and change in developmental time or lack of maturation (Diggle et al., 2011). Among these, cell death is an important strategy that arrests the development of sex organ in unisexual flowers. For instance, by cell death, maize ends gynecium development (Cheng et al., 1983) and Thymelaea hirsuta ends meiosis (Caporali et al., 2006). The sterility of pistil in the male flowers of European grape might arise due to the abnormal division of megaspore or female gametophyte, 
and the subsequent PCD of external nucellar cells (Caporali et al., 2003). Sometimes cell death results in the formation of gaps in the floral organs, thus, acting as obstacles for nutrition transportation and information negotiation. For instance, Wetzstein et al. (2011) observed different types of arrested development of pistil in aborted Punica granatum flowers, one of which exhibited gaps between the inner and outer integuments. Rosati et al. (2011) found that the abnormity of integument formation breaks the negotiation between the integument and embryo sac, resulting in pistil abortion. In the present study, the organelles were not identified from day 6 after treatment, implying the occurrence of PCD of the nucellar cell. Furthermore, no cell layer in the outer edge of the nucellus tissue was stained with safranin-fast green dye, leaving a gap between the nucellus and integument. This is consistent with the findings of Wang et al. (2013).

Overall, pistil abortion in male amur grape might be caused by the PCD of nucellar cells that starts before the formation of the four-nucleate embryo sac. The successful gender conversion by CPPU treatment provides more opportunities to evaluate and use male amur grape. Herein, we have provided cytological evidence for gender conversion in amur grape. However, the exact mechanism remains unknown, and further studies should concentrate on mapping, cloning, and the expression of gender determining gene in amur grape.

\section{Literature Cited}

Ai, J., A.M. Li, C.Y. Li, J. Wang, and Y.J. Shen. 2002. The effect of cytokinin on sex conversion of male plants of Vitis amurensis. Acta Hort. Sinica 29:163-164.

Ainsworth, C., A. Rahman, J. Parker, and G. Edwards. 2005. Intersex inflorescences of Rumex acetosa demonstrate that sex determination is unique to each flower. New Phytol. 165:711-720.

Aryal, R. and R. Ming. 2014. Sex determination in flowering plants: Papaya as a model system. Plant Sci. 217-218:56-62.

Bensen, R.J., G.S. Johal, V.C. Crane, J.T. Tossberg, P.S. Schnable, R.B. Meeley, and S.P. Briggs. 1995. Cloning and characterization of the maize Anl gene. Plant Cell 7:75-84.

Blasi, P., S. Blanc, S. Wiedemann-Merdinoglu, E. Prado, E.H. Rühl, P. Mestre, and D. Merdinoglu. 2011. Construction of a reference linkage map of Vitis amurensis and genetic mapping of Rpv8, a locus conferring resistance to grapevine downy mildew. Theor. Appl. Genet. 123:43-53.

Caporali, E., E. Roccotiello, L. Cornara, G. Casazza, and L. Minuto. 2006. An anatomical study of floral variation in Thymelaea hirsuta (L.) Endl. related to sexual dimorphism. Plant Biosyst. 140:123-131.

Caporali, E., A. Spada, G. Marziani, O. Failla, and A. Scienza. 2003. The arrest of development of abortive reproductive organs in the unisexual flower of Vitis vinifera ssp. silvestris. Sex. Plant Reprod. 15:291-300.

Charlesworth, D. 2002. Plant sex determination and sex chromosomes. Heredity 88:94-101.

Cheng, P.C., R.I. Greyson, and D.B. Walden. 1983. Organ initiation and the development of unisexual flowers in the tassel and ear of Zea mays. Amer. J. Bot. 70:450-462.

Cui, Y.K., Q.J. Xu, Y.H. Sun, and Z. Meng. 2011. Characterization of unisexual flower development in the basal angiosperm Hedyosmum orientale (Chloranthaceae). Chinese Bul. Bot. 46:489-497.

DeLong, A., A. Calderon-Urrea, and S.L. Dellaporta. 1993. Sex determination gene TASSELSEED2 of maize encodes a short-chain alcohol dehydrogenase required for stage-specific floral organ abortion. Cell 74:757-768.

Diggle, P.K., V.S. Di Stilio, A.R. Gschwend, E.M. Golenberg, R.C. Moore, J.R.W. Russell, and J.P. Sinclair. 2011. Multiple developmental processes underlie sex differentiation in angiosperms. Trends Genet. 27:368-376.

Di Stilio, V.S., E.M. Kramer, and D.A. Baum. 2005. Floral MADS box genes and homeotic gender dimorphism in Thalictrum dioicum (Ranunculaceae)-A new model for the study of dioecy. Plant J. 41:755-766.

Dransfield, J., N.W. Uhl, C.B. Amussen, W.J. Baker, M. Harley, and C.L. Lewis. 2008. Genera palmarum. The evolution and classification of palms. 2nd ed. Kew Publ., Kew, UK.

Dubrovina, A.S., K.V. Kiselev, V.S. Khristenko, and O.A. Aleynova. 2015. VaCPK20, a calcium-dependent protein kinase gene of wild grapevine Vitis amurensis Rupr., mediates cold and drought stress tolerance. J. Plant Physiol. 185:1-12.

Farbos, I., M. Oliveira, I. Negrutiu, and A. Mouras. 1997. Sex organ determination and differentiation in the dioecious plant Melandrium album (Silene latifolia): A cytological and histological analysis. Sex. Plant Reprod. 10:155-167.

Gouvêa, C.F., M.C. Dornelas, and A.P. Martinelli. 2008. Characterization of unisexual flower development in the endangered mahogany tree Swietenia macrophylla King. (Meliaceae). Bot. J. Linn. Soc. 156:529-535.

Hashizume, T. and M. Iizuka. 1971. Induction of female organs in male flowers of vitis species by zeatin and dihydrozeatin. Phytochemistry 10:2653-2655.

He, R.R., J. Wu, Y.L. Zhang, C.B. Agüero, X.L. Li, S.L. Liu, C.X. Wang, M.A. Walker, and J. Lu. 2017. Overexpression of a thaumatin-like protein gene from Vitis amurensis improves downy mildew resistance in Vitis vinifera grapevine. Protoplasma 254:1579-1589.

Hou, Y.N., Y. Qin, and F.L. Li. 2005. Morphological and histochemical studies on sex differentiation in Gymnocladus dioicus. J. Beijing For. Univ. 27:48-53.

Huang, H. 1980. Viticulture in China. HortScience 15:461-466.

Iizuka, M. and T. Hashizume. 1968. Induction of female organs in staminate grape by 6-substituted adenine derivatives. Jpn. J. Genet. 43:393-394.

Jiao, L., Y.L. Zhang, J. Wu, H.Q. Zhang, and J. Lu. 2015. A novel U-Box protein gene from "Zuoshanyi" grapevine (Vitis amurensis Rupr. cv.) involved in cold responsive gene expression in Arabidopsis thanliana. Plant Mol. Biol. Rpt. 33:557-568.

Kamachi, S., H. Mizusawa, S. Matsuura, and S. Sakai. 2000. Expression of two 1-aminocyclopropalle-1-carboxylate synthase genes, $C S$ - $A C S 1$ and $C S$ - $A C S 2$, correlated with sex phenotypes in cucumber plants (Cucumis sativus L.). Plant Biotechnol. 17:69-74.

Kamachi, S., H. Sekimoto, N. Kondo, and S. Sakai. 1997. Cloning of a cDNA for a 1-aminocyclopropane-1-carboxylate synthase that is expressed during development of female flowers at the apices of Cucumis sativus L. Plant Cell Physiol. 38:1197-1206.

Kater, M.M., J. Franken, K.J. Carney, L. Colombo, and G. Angenent. 2001. Sex determination in the monoecious species cucumber is confined to specific floral whorls. Plant Cell 13:481-493.

Kaul, R.B. 1995. Reproductive structure and organogenesis in a cottonwood, Populus deltoides (Salicaceae). Intl. J. Plant Sci. 156:172180.

Kender, W.J. and G. Remaily. 1970. Regulation of sex expression and seed development in grapes with 2-chloroethylphosphonic acid. HortScience 5:491-492.

Knopf, R.R. and T. Trebitsh. 2006. The Female-specific CS-ACS1G gene of cucumber. A case of gene duplication and recombination between the non-sex-specific 1-aminocyclopropane-1-carboxylate synthase gene and a branched-chain amino acid transaminase gene. Plant Cell Physiol. 47:1217-1228.

Lardon, A., S. Georgiev, A. Aghmir, G. Le Merrer, and I. Negrutiu. 1999. Sexual dimorphism in white campion: Complex control of carpel number is revealed by $\mathrm{Y}$ chromosome deletions. Genetics 151:1173-1185.

Li, D., Y. Wan, and P. He. 2008. Relatedness of resistance to anthracnose and to white rot in Chinese wild grapes. Vitis 47:213215 . 
Li, J.T., N. Wang, H.P. Xin, and S.H. Li. 2013. Overexpression of $V a C B F 4$, a transcription factor from Vitis amurensis, improves cold tolerance accompanying increased resistance to drought and salinity in Arabidopsis. Plant Mol. Biol. Rpt. 31:1518-1528.

Li, X.L., J. Wu, L. Yin, Y. Zhang, J. Qu, and J. Lu. 2015a. Comparative transcriptome analysis reveals defense-related genes and pathways against downy mildew in Vitis amurensis grapevine. Plant Physiol. Chem. 95:1-14.

Li, X.Y., Y.M. Yang, J. Ai, S.T. Fan, Y.X. Liu, Z.X. Wang, Y. Zhao, Q.T. Zhang, P.L. Xu, H.Y. Qin, and Y.J. Shen. 2015b. Collection, conservation, evaluation and utilization of Vitis amurensis germplasm resources in China. Acta Hort. 1082:79-86.

Ma, Y.Y., Y.L. Zhang, H. Shao, and J. Lu. 2010. Differential physiobiochemical responses to cold stress of cold-tolerant and non-tolerant grapes (Vitis L.) from China. J. Agron. Crop Sci. 196:212-219.

Matsunaga, S., S. Kawano, H. Takano, H. Uchida, A. Sakai, and T. Kuroiwa. 1996. Isolation and developmental expression of male reproductive organ-specific genes in a dioecious campion, Melandrium album (Silene latifolia). Plant J. 10:679-689.

Mibus, H. and T. Tatlioglu. 2004. Molecular characterization and isolation of the $F / f$ gene for femaleness in cucumber (Cucumis sativus L.). Theor. Appl. Genet. 109:1669-1676.

Ming, R., A. Bendahmane, and S.S. Renner. 2011. Sex chromosomes in land plants. Annu. Rev. Plant Biol. 62:485-514.

Mitchell, C.H. and P.K. Diggle. 2005. The evolution of unisexual flowers: Morphological and functional convergence results from diverse developmental transitions. Amer. J. Bot. 92:1068-1076.

Moore, J.N. 1970. Cytokinin-induced sex conversion in male clones of Vitis species. J. Amer. Soc. Hort. Sci. 95:387-393.

Negi, S.S. and H.P. Olmo. 1966. Sex conversion in a male Vitis vinifera L. by a Kinin. Science 152:1624.

Park, J.H., Y. Ishikawa, R. Yoshida, A. Kanno, and T. Kameya. 2003. Expression of $A O D E F$, a B-functional MADS-box gene, in stamens and inner tepals of the dioecious species Asparagus officinalis L. Plant Mol. Biol. 51:867-875.

Rosati, A., S. Caporali, A. Paoletti, and F. Famiani. 2011. Pistil abortion is related to ovary mass in olive (Olea europaea L.). Scientia Hort. 127:515-519.

Scutt, C.P., Y. Li, S.E. Robertson, M.E. Willis, and P.M. Gilmartin. 1997. Sex determination in dioecious Silene latifolia. Effects of the Y chromosome and the parasitic smut fungus (Ustilago violacea) on gene expression during flowers development. Plant Physiol. 114:969-979.

Sherry, R.A., K.J. Eckard, and E.M. Lord. 1993. Flower development in dioecious Spinacia oleracea (Chenopodiaceae). Amer. J. Bot. 80:283-291.

Song, R.G., W.P. Lu, J. Wang, T.J. Guo, and Y.J. Shen. 2000. The characteristics, evaluation and necessary culture techniques of wild grape variety. Sino-Overseas Grapevine Wine 2000(3):22-25.

Strittmatter, L.I., V. Negrón-Ortiz, and R.J. Hickey. 2002. Subdioecy in Consolea spinosissima (Cactaceae): Breeding system and embryological studies. Amer. J. Bot. 89:1373-1387.

Trebitsh, T., J.E. Staub, and S.D. O'Neill. 1997. Identification of a 1aminocyclopropane-1-carboxylic acid synthase gene linked to the female (F) locus that enhances female sex in cucumber. Plant Physiol. 113:987-995.

Wan, Y.Z., H. Schwaninger, P.C. He, and Y.J. Wang. 2007. Comparison of resistance to powdery mildew and downy mildew in Chinese wild grapes. Vitis 46:132-136.

Wang, Z.X., Z.Q. Jiao, P.L. Xu, L. Chen, J. Ai, X.M. Liu, and Y.M. Yang. 2013. Bisexual flower ontogeny after chemical induction and berry characteristics evaluation in male Vitis amurensis Rupr. Scientia Hort. 162:11-19.

Wetzstein, H.Y., N. Ravid, E. Wilkins, and A.P. Martinelli. 2011. A morphological and histological characterization of bisexual and male flower types in pomegranate. J. Amer. Soc. Hort. Sci. 136:83-92.

Xu, P.L., Z.Q. Jiao, Z.X. Wang, J. Ai, Y.M. Yang, Q.T. Zhang, H.Y. Qin, Y.X. Liu, Y. Zhao, and S.T. Fan. 2013. Proteomic analysis of sex conversion induced by CPPU in male grapevine of Vitis amurensis. Vitis 52(4):177-184.

Yamasaki, S., N. Fujii, S. Matsuura, H. Mizusawa, and H. Takahashi. 2001. The M locus and ethylene-controlled sex determination in andromonoecious cucumber plants. Plant Cell Physiol. 42:608-619. Yamasaki, S., N. Fujii, and H. Takahashi. 2000. The ethyleneregulated expression of CS-ETR2 and CS-ERS genes in cucumber plants and their possible involvement with sex expression in flowers. Plant Cell Physiol. 41:608-616.

Zhang, Q.T., S.T. Fan, W.P. Lu, R.G. Song, Y.M. Yang, and J. Ai. 2015. Breeding progress of amur grape (Vitis amurensis Rupr.) in China. Acta Hort. 1082:33-36. 